\title{
Dr. Rollas: A Humble and Persistent Man
}

\section{Dr. Rollas: Mütevazi ve Mücadeleci Bir Kişilik}

Ozkan TEHLI, Caglar TEMIZ

Gulhane Military Medical Academy, Department of Neurosurgery, Turkey

Corresponding Author: Ozkan TEHLI / E-mail: ozkantehli@gmail.com

\begin{abstract}
Dr. Zinnur Rollas is the founder of the Department of Neurosurgery at the Gulhane Military Medical Academy (GMMA). He was educated in the United States and returned to Turkey in order to practice neurosurgery. He is also the first surgeon who performed pediatric neurosurgical procedures at GMMA. Dr. Rollas operated on many pediatric cases of meningocele, myelomeningocele, encephalocele, hydrocephalus and trauma. He not only performed the surgeries but also took the pictures and recorded the data of the patients. Unfortunately, he did not publish any of these cases. In this paper, we tried to document his experience on pediatric neurosurgery, and to summarize the evolution of pediatric neurosurgery at GMMA.
\end{abstract}

KEYWORDS: Pediatric neurosurgery, Gulhane Military Medical Academy, Zinnur Rollas

öz

Dr. Zinnur Rollas Gülhane Askeri Tıp Akademisi'nde (GATA) Nöroşirürji Kliniğinin kurucusudur. ABD'de eğitim görmüştür ve nöroşirürji yapmak üzere Türkiye'ye dönmüştür. Kendisi aynı zamanda GATA'da ilk pediatrik nöroşirürjikal operasyonları gerçekleştiren cerrahtır. Dr. Rollas pek çok pediatrik meningosel, myelomeningosel, ensefalosel, hidrosefali ve travma olgusunu opere etmiştir. Sadece cerrahileri yapmakla kalmamış aynı zamanda resimler çekmiş ve kayıtlar tutmuştur. Maalesef olgularından hiçbirisini yayımlamamıştır. Bu makalede, onun pediatrik nöroşirürji üzerine deneyimlerini göstermeye çalıştık, aynı zamanda GATA'da pediatrik nöroşirürji'nin gelişimini özetledik.

ANAHTAR SÖZCÜKLER: Pediatrik nöroşirürji, Gülhane Askeri Tıp Akademisi, Zinnur Rollas

\section{HISTORICAL PERSPECTIVE}

The Roots of Gulhane Military Medical Academy goes back to the establishment of the Military Medical School in 1827 during the Ottoman Empire period. Cemil Pasha was the first surgeon who performed neurosurgical procedures in this school in $1889(7,9)$. The Military Medical School progressively expanded, and was modernized and renamed as Gülhane Military Medical Academy (GMMA) in 1898. As explained in detail in the extensive report of Timurkaynak, neurosurgical procedures at GMMA were carried out by the general surgeons, most of whom were invited from European countries, until 1957 (9). In 1957, Dr.Zinnur Rollas founded the Department of Neurosurgery at GMMA as an independent unit (Figure 1). He was a neurologist and completed his neurosurgery residency training under the supervision of Dr. Harry E. LeFever at the Ohio State University between 1954 and 1956. Dr. Rollas was particularly involved with congenital malformations, hydrocephalus, trauma and intracranial tumors. For instance, looking back the past medical records of pediatric patients operated by Dr. Rollas in 1957, one can see that he operated on meningocele and meningoencephalocele patients. These patients survived after the operations (Figures $2 A, B ; 3 A, B ; 4$ ). $\mathrm{He}$ also operated on patients with encephalocele (Figure 5) and performed numerous cerebrospinal fluid diversion procedures in children with hydrocephalus (Figure 6). He also pictured all of his cases. Overall, management of pediatric neurosurgical cases by Dr. Rollas was satisfactory with acceptable morbidity and mortality rates considering the general conditions of that time including the insufficiency in the equipment of the operating rooms and the difficulties in anesthesia induction, maintenance and timely adequate replacement of blood loss in infants and children. In this regard, Dr. Rollas did a remarkable job and he deserves the tribute as being the father of modern pediatric neurosurgery at GMMA. However, he did not publish any of these pediatric cases. After his retirement in 1960, one of his residents, Dr. Hamit Ziya Gökalp went to the United States for neurosurgery training. He returned to GMMA and began to practice neurosurgery. Regular neurosurgical education and training was initiated by Dr. Gökalp and neurosurgical procedures on children were carried out by his team. Advances in anesthesiology and microsurgical techniques suported pediatric neurosurgery at GMMA to a great extent. The complication rate was significantly reduced and the suboptimal conditions of old times including the inability to cope with blood loss, lack of pediatric intensive care units, inadequate operating room equipment and inadequate surgical material were all overcome satisfactorily.

Teamwork became the mode of practice for pediatric neurosurgery at GMMA by 1990's and most pediatric cases were performed by Dr. Alper Baysefer and Dr. Melih Akay. The first reports were also published by these team during the 


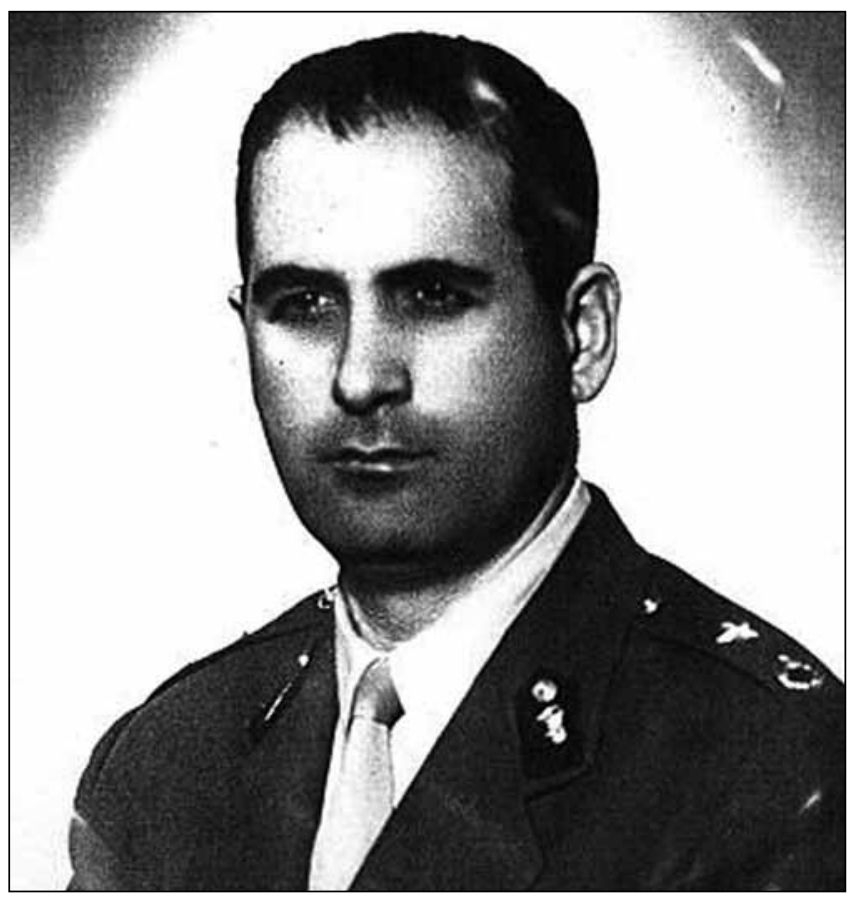

Figure 1: Dr. Zinnur Rollas (Major) is the pioneer of pediatric neurosurgery at GMMA. first half of 2000 s $(1,2,3,4,5,6,8)$. They operated on intracranial and spinal tumors, peripheral nerve lesions, congenital malformations and hydrocephalus. The endoscope was introduced during these years and the first endoscopic third ventriculostomy was performed. Today, an endoscope is routinely used in the treatment of hydrocephalus, pituitary tumors and arachnoid cysts at GMMA. Additionally, navigation and intraoperative magnetic resonance imaging systems were integrated into our surgical unit and are now available for pediatric cases and particularly for low-grade glial tumors. Dr. Ahmet Çolak, professor of neurosurgery is the pioneer of pediatric neurosurgery at Haydarpasa Training Hospital, Istanbul, affiliated hospital of GMMA. He was trained on pediatric neurosurgery at the Children's Hospital of Pittsburgh and worked with Drs. Pollack and Albright. Following his return to Turkey, he managed pediatric cases at Haydarpasa Training Hospital. Currently, Dr. Colak is a privileged and active member of the Pediatric Neurosurgery Group of the Turkish Neurosurgical Society.

Although pediatric neurosurgery is a specific discipline, it is not an official subspecialty and does not have its own certification process in Turkey. However, various pediatric cases including patients with congenital malformations,
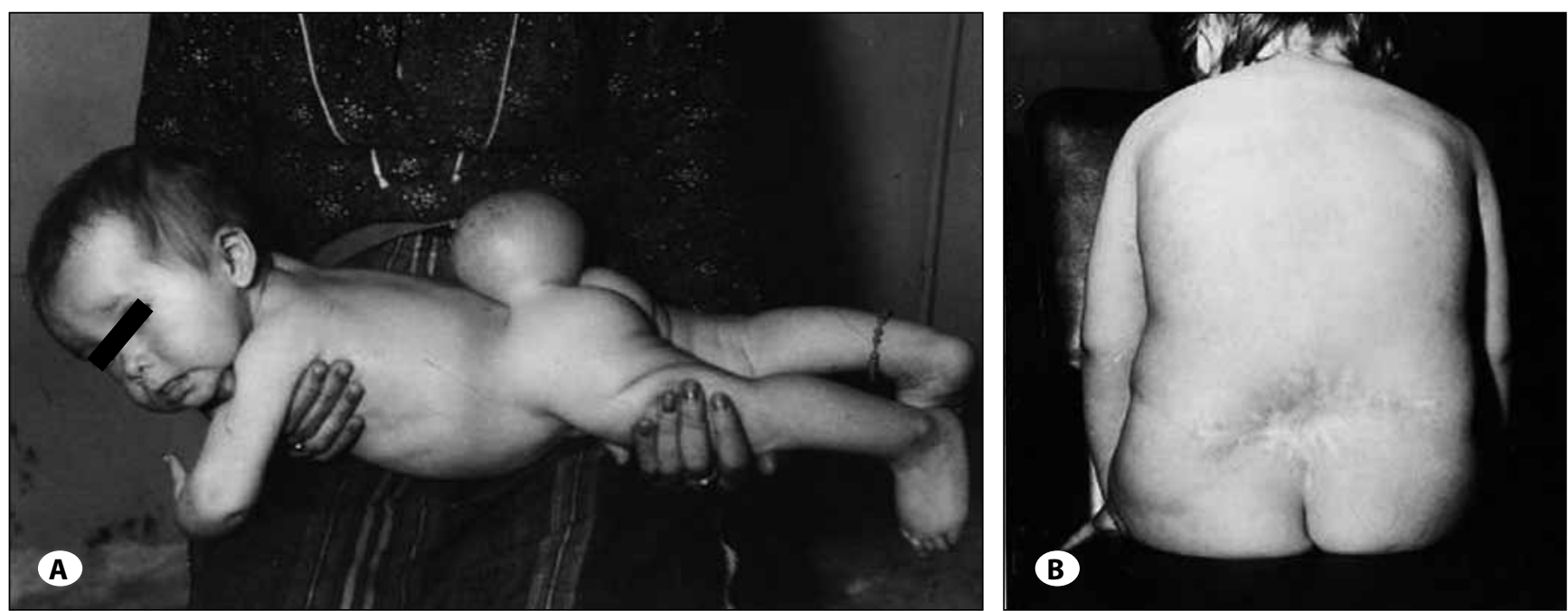

Figure 2: A sacral meningocele operated by Dr. Rollas. (A) Preoperative and (B) postoperative views of the child.
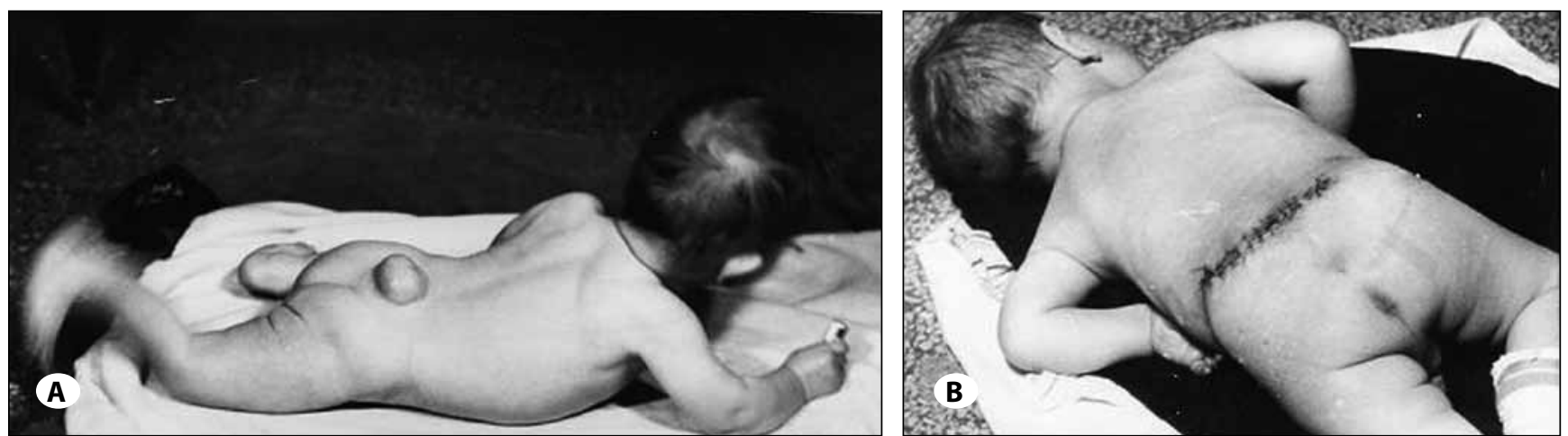

Figure 3: A lumbar meningocele patient. (A) Preoperative and (B) early postoperative view. 


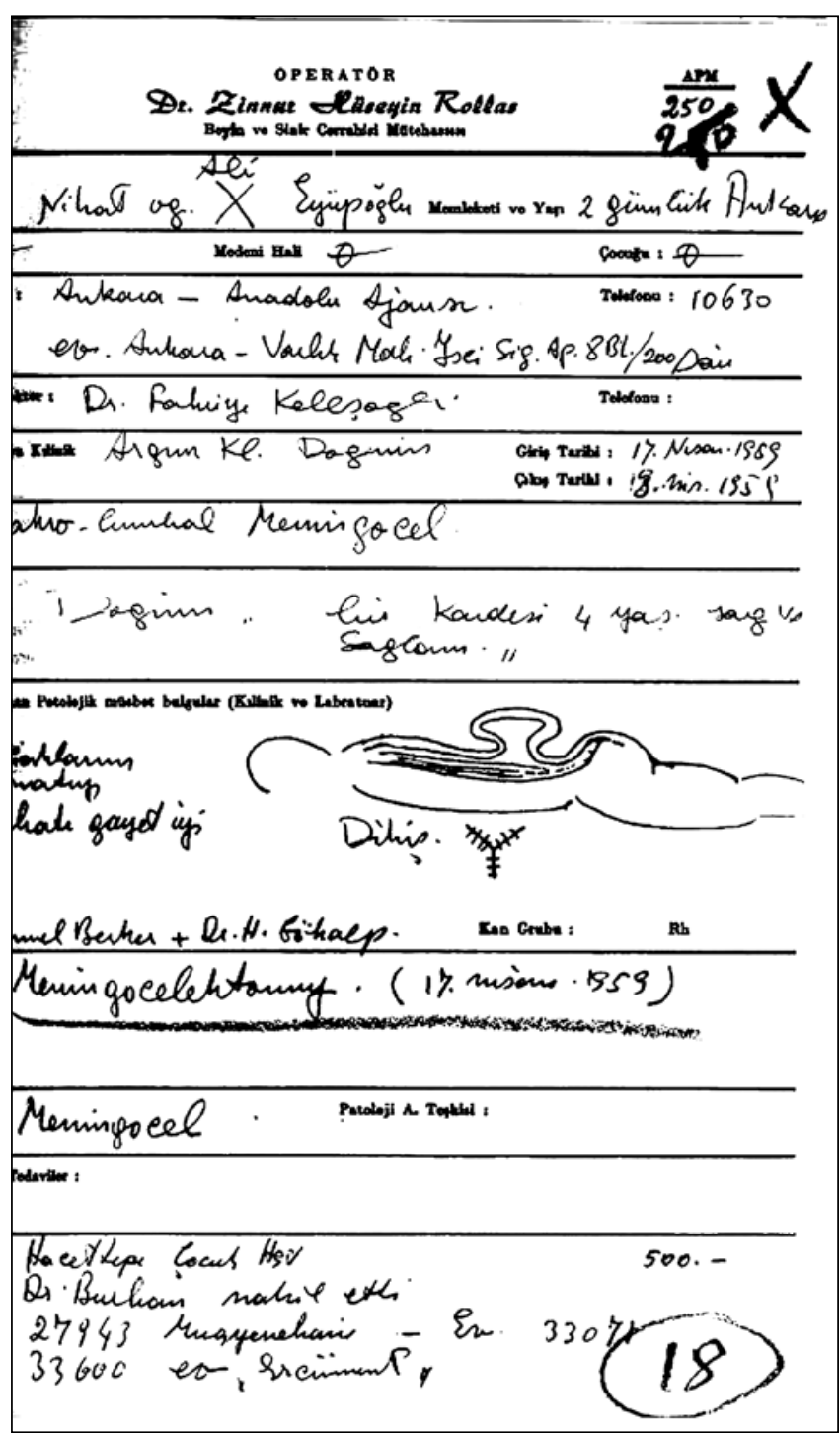

Figure 4: Operation note of Dr. Rollas written in 1959. He depicted and narrated a'meningocelectomy' operation.

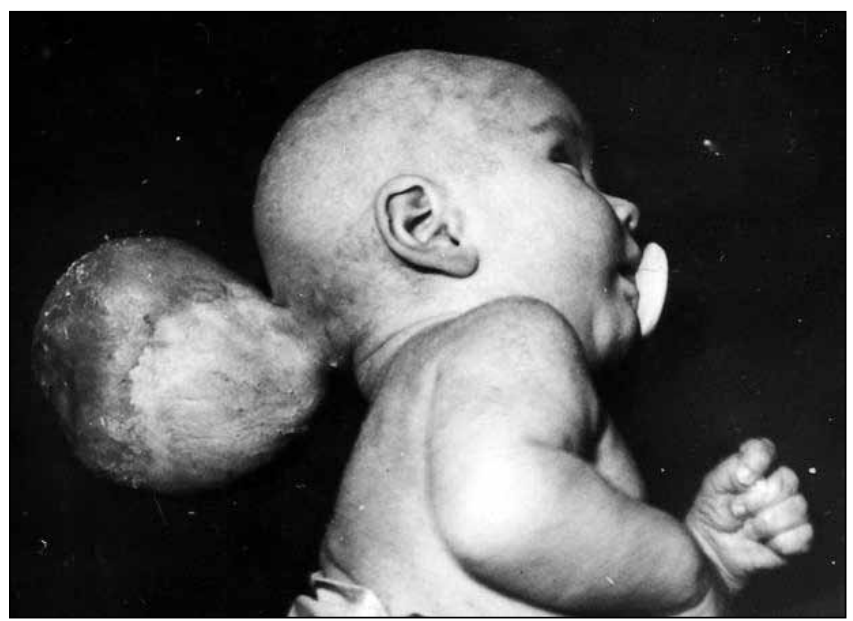

Figure 5: A patient with occipital encephalocele.

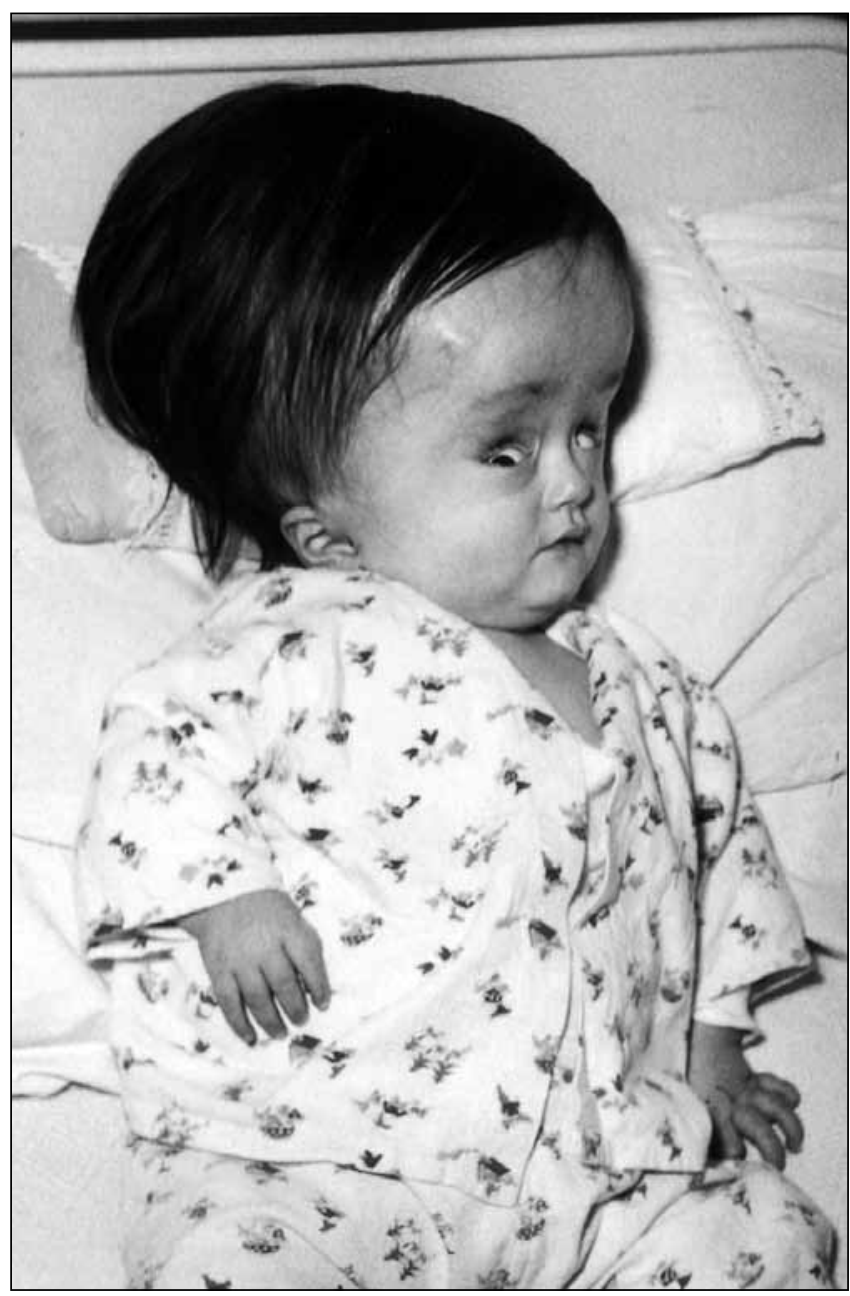

Figure 6: A child with hydrocephalus operated on by Dr. Rollas.

tumors, and hydrocephalus are being treated optimally at GMMA. Since the Dr. Rollas period, the number of pediatric cases operated at GMMA has increased at a steady fashion with approximately 50 cases per year at present. Among pediatric cases, hydrocephalus and spina bifida patients make up the largest portion, followed by trauma, tumor, and epilepsy cases.

In conclusion, progress of pediatric neurosurgery at GMMA is noteworthy. Since 1957, the department of neurosurgery at GMMA has had an important role in the development of neurosurgery in Turkey. Comparable to the pioneering role undertaken by Dr. Gokalp in nourishing adult neurosurgery at GMMA, Dr. Rollas and his colleague Dr. Baysefer did a similar job in establishing and supporting pediatric neurosurgery at GMMA. Dr. Rollas transferred and practiced the surgical knowledge and skills he gained in the United States remarkably well to his homeland at GMMA. With its strong tradition of clinical teaching and research experience, GMMA will hopefully continue to be one of the major contributors to Turkish Pediatric Neurosurgery in the years to come (in memoir of Dr. Zinnur Rollas who recently passed away on April $2^{\text {nd }}$ of 2010). 


\section{REFERENCES}

1. Akay KM, Izci Y, Baysefer A: Dorsal bony septum: A split cord malformation variant. Pediatr Neurosurg 36:225-228, 2002

2. Akay KM, Izci Y, Baysefer A, Atabey C, Kismet E, Timurkaynak E: Surgical outcomes of cerebellar tumors in children. Pediatr Neurosurg. 40:220-225, 2004

3. Akay KM, Izci Y, Baysefer A, Timurkaynak E: Composite type of split cord malformation: Two different types at three different levels: Case report. J Neurosurg 102(4 Suppl):436-438, 2005

4. Baysefer A, IzciY, Erdoğan E: Lateral intrathoracic meningocele associated with a spinal intradural arachnoid cyst. Pediatr Neurosurg 35:107-110, 2001

5. Baysefer A, Akay KM, Izci Y, Kayali H, Timurkaynak E: The clinical and surgical aspects of spinal tumors in children. Pediatr Neurol 31:261-266, 2004
6. Baysefer A, Izci Y, Akay KM, Kayali H, Timurkaynak E: Surgical outcomes of ulnar nerve lesions in children. A retrospective clinical study. Pediatr Neurosurg 40:107-111, 2004

7. Mut M, Dinç G, Naderi S: On the report of the first successful surgical treatment of brain abscess in the Ottoman Empire by Dr. Cemil Topuzlu in 1891. Neurosurgery 61:869-872, 2007

8. Secer HI, Kural C, Kaplan M, Kilic A, Duz B, Gonul E, Izci Y: Comparison of the efficacies of antibiotic-impregnated and silver-impregnated ventricular catheters on the prevention of infections. An in vitro laboratory study. Pediatr Neurosurg 44:444-447, 2008

9. Timurkaynak E, Izci Y, Acar F: 116 years (1889-2005) of neurosurgical practice and education at Gulhane Military Medical Academy. Neurosurgery 58:577- 581, 2006 